\title{
Disclosure of Critical Accounting Judgments and Key Sources of Estimation Uncertainty in the Financial Statements of Companies in Nigeria
}

\author{
Clement Chiahemba Ajekwe*, Adzor Ibiamke \\ Email address: \\ cajekwe@bsum.edu.ng (C. C. Ajekwe), nickibiamke@yahoo.com (A. Ibiamke) \\ ${ }^{*}$ Corresponding Author
}

Department of Accounting, Faculty of Management Sciences, Benue State University, Makurdi, Nigeria

To cite this article:

Clement Chiahemba Ajekwe, Adzor Ibiamke. Disclosure of Critical Accounting Judgments and Key Sources of Estimation Uncertainty in the Financial Statements of Companies in Nigeria. Journal of Finance and Accounting. Vol. 7, No. 1, 2019, pp. 22-31.

doi: $10.11648 /$ j.jfa.20190701.14

Received: December 17, 2018; Accepted: December 28, 2018; Published: May 11, 2019

\begin{abstract}
This paper performs a thematic survey of published financial statements of 17 consumer goods companies listed on the Nigerian Stock Exchange (NSE) to investigate their level of compliance with regulatory requirements regarding disclosure of critical accounting judgments and major sources of estimation uncertainties in their financial statements. High quality disclosures in this area enable users to assess the quality of managements accounting policy decisions and the likelihood of future changes in the amounts appearing in the financial statements in a way that generic disclosures do not. Data was collected from the annual reports and accounts of the sampled companies in the financial reporting year ended in 2017. Using descriptive statistics and content analysis, it was found that firms provide some disclosures, but the information is not sufficiently informative to give users meaningful insights. Overall, the level of disclosure fell short of the intentions of the relevant regulatory requirements. The findings suggest that in addition to the guidance in the IFRS illustrative examples, it may be necessary to train accountants and auditors in Nigeria on disclosing accounting critical judgments and key sources of estimation uncertainties in compliance with regulatory intentions and requirements thereby increasing the informational value of these disclosures in financial reports.
\end{abstract}

Keywords: Disclosure, Estimates, Judgments, Nigerian Stock Exchange (NSE), Sensitivity Analysis, Uncertainty

\section{Introduction}

Accurate and timely disclosures in annual reports are critical to the effective operations of capital markets [1]. Financial statements' disclosures are crucial to the firm's stakeholders in mitigating information asymmetry between management and outsiders as suggested by the agency theory. According to Levitt [2] quality financial statements disclose events in the period in which they occur, not before, and not after. This implies that there is no extra "rainy day" reserves, no deferral of loss recognition, and actual volatility is not "smoothed away" to create an artificial picture of steady and consistent growth. This scenario can be achieved only with proper disclosure of critical accounting judgements and critical estimates with their sources of estimation uncertainties.
The assertion that quality financial reporting is possible only through a proper and comprehensive disclosure of judgements and estimates that management makes in preparing financial statements have its roots in both the academic and practitioner expectations and writings. Barth [3] raised many of the relevant issues with respect to subjective estimates, demonstrating the need for increased disclosure, both of assumptions underlying accounting estimates and the sensitivities of these estimates to uncertainties in the underlying assumptions. Practitioner expectations are contained in both the international and national accounting standards as well as professional accounting bodies. For instance, the International Financial Reporting Standards Foundation (IFRSF) [4], states that "to a large extent, financial reports are based on estimates, judgements and models rather than being exact depictions". 
Making estimates implies a certain level of subjectivity; two different estimates for an item can result in presenting a different accounting picture regarding the financial health and performance of a company. Taking this fact as a study problem, Sacer, Malis and Pavic [5] sought to assess critical areas for management judgments relating to non-current intangible and tangible assets. In order to do this, they designed and applied research models for empirically testing accounting estimates' influence on financial statements. Their research confirmed the volatility of the financial condition and performance of a company as a result of different accounting estimates, and hence the need to disclose the critical accounting judgements and estimates made in the preparation of financial statements. The Institute of Chartered Accountants of Scotland (ICAS) [6], also explains that the 'diamond of trust' (i.e., preparers, investors, auditors, accounting standard setters and regulators) allow management to exercise judgements in presenting economic reality of business events. Consequently, the use and disclosure of judgments and estimates in the financial statements is essential to a large extent for the determination of the reliability of those statements.

Although judgements and estimates are inevitable in financial reporting, they must be done in good faith and disclosed sufficiently in the financial statements because they pose a significant effect on the carrying amounts of assets, liabilities, revenue, expenses and contingencies. Indeed, as the complexity and subjectivity of judgments increase, not only does the inherent level of precision in the financial statements decrease, there is also the likelihood that materially different amounts would be reported under different conditions or using different assumptions [7]. Thus, disclosures about the key judgements and the underlying sources of estimates that management make are necessarily valuable to investors and other users because they help in the assessment of an entity's financial position and performance. High quality disclosure in this area according to Herdman [8] include quantified information such as sensitivities on how changes in estimates could affect the following year's results to enable user-assessments of the quality of management's accounting policy decisions and the likelihood of future changes in a way that generic disclosures do not. Without adequate disclosures about judgments and sources of estimates, investors and other users of financial statements might think that the numbers at the bottom of the financial statements such as net income, book value of assets are the conclusive, perhaps even infallible measures of a reporting entity's performance and position in a reporting period. That is not entirely true. Because corporations make judgments and assumptions concerning the future, the resulting accounting measures will, by definition, seldom equal to the related actual results. It is important, therefore, that the users of accounts understand the judgements and sources and (un)certainties of estimates in the application of accounting policies and the entire accounting measurement process.

The main purpose of this paper is to perform a thematic survey of the published financial statements of companies in
Nigeria, to investigate their compliance with regulatory requirements to disclose critical judgments and major sources of estimation uncertainties. In trying to achieve this objective the question that the paper intends to answer is whether firms in Nigeria are complying with the IFRS requirements to disclose major judgements and sources of estimation uncertainties in their annual financial reports. In particular, this paper investigates: (i) the extent to which key judgements and sources of estimation uncertainty affecting the future are separately disclosed in the financial statements of companies in Nigeria; (ii) whether disclosures explain clearly the specific judgements made and their effect on the financial statements; (iii) what constitutes the critical judgments and sources of estimation uncertainties in the financial statements of companies in Nigeria; (iv)whether the disclosures include sensitivities or ranges of outcomes, so that users of the financial statements can fully understand the potential effect of estimates made; and (v)whether disclosures avoid mere repetition of accounting policies and generic statements without quantifications that focus on how particular decisions or assumptions might affect the entity's results and financial position.

The study is appropriate and significant at this point in time for at least two reasons. First, it is six and half years since Nigeria mandatorily adopted the IFRS in January 2012; it is appropriate to assess the disclosures relating to the use of judgment and estimates while preparing financial statements. Secondly, the results of this study will provide preparers, auditors and users of financial statements with factual information which may encourage discussion and debate on the invocation of critical accounting judgements and estimates in financial statements by Nigerian listed companies. Overall, this investigation matters because such information is valuable to investors as it helps them to assess an entity's financial position and performance and to understand the sensitivities to changes in assumptions within one year or over the longer term. This paper is also important given the current concerns about the decreasing relevance of financial statements and the increasing complexity of accounting reports that is brought about by recent complex business environment and IFRS adoption [9].

The rest of the paper is organised as follows: IFRS disclosure requirements for judgments and estimation uncertainties and related accounting literature is provided in the next section. The study describes the methods employed in the following section, presents its findings in section 4 and discusses the findings in section 5 followed by conclusions in section 6 .

\section{IFRS Disclosure Requirements for Judgments and Estimates}

Sources of estimation uncertainties relate to accounting estimates that require management's most difficult, subjective or complex judgments in measuring the carrying amounts of the entity's assets and liabilities [10]. As the 
number of variables and assumptions affecting future outcomes increase, the judgements related thereto become more subjective and complex and the higher the potential for a material adjustment to the carrying amounts of assets and liabilities increase accordingly. The existing requirements for disclosure of critical accounting judgments and key sources of estimation uncertainties are contained mainly in IAS 1 Presentation of Financial Statements particularly in paragraphs 122 and 125 .

IAS 1:122 mandates the disclosure of those judgements that management has made when applying a reporting entity's accounting policies ${ }^{1}$ and that have the most significant effect on the amounts recognised in the financial statements. The language used makes clear that not all judgements should be disclosed; judgments must relate to a significant policy and the judgement must have materially affected the reported numbers. Disclosures of key judgements do not usually address measurements although they may do when the issue relates to determining the appropriate measurement basis (e.g. fair value, amortised cost etc.) rather than what goes into arriving at the amounts recognised [11]. In practice, these decisions may be finely balanced and often considered by the reporting entity's senior management, the audit committee and external auditors. The disclosure will be of sufficient detail to help readers understand how policies have been applied and to enable them to compare judgements between different companies' financial statements. Examples of judgements that do not involve estimations according to IAS 1:123 are:

(i). when substantially all the significant risks and rewards of ownership of assets are transferred;

(ii). whether, in substance, particular sales of goods are financing arrangements and therefore do not give rise to revenue

(iii). whether or not to consolidate an investee company;

(iv). whether a company is acting as principal or agent;

(v). whether the terms of a financial asset give rise to cash flows that are solely payments of principal and interest on the principal loan amount outstanding.

Other international standards that also mandate judgment disclosures are: (a) IFRS 12 Disclosure of Interests in Other Entities requires an entity to disclose the judgements it has made in determining whether it controls another entity and (b) IAS 40: Investment Property requires disclosure of the criteria developed by the entity to distinguish investment property from owner-occupied property and property held for sale in the ordinary course of business, when classification of the property is difficult.

IAS 1:125 stipulates disclosure of the key sources of estimation uncertainty, at the reporting date, that have a significant risk of causing a material adjustment to the carrying amounts of assets and liabilities within the next financial year. All three factors (in bold characters) apply,

1 Accounting policies are the specific principles, bases, conventions, rules and practices applied by an entity in preparing and presenting financial statements (IAS 8, paragraph. 5). which limits the number of items we might expect to see reported. Longer term uncertainties may also be useful for users of financial statements. However, these additional disclosures should be explained and clearly differentiated from those relating to estimates with genuine risk of a material effect in the following year. In these circumstances, as has already been noted by the IASB in the Basis for Conclusions to IAS 1, disclosure requirements under IAS 1.125 would apply in respect of relatively few assets and liabilities, or their classes, because they relate only to the most difficult, subjective or complex judgments. Other international standards also mandate disclosure of estimation uncertainty assumptions. They are: (a) IAS 37: Provisions, Contingent Liabilities and Contingent Assets which requires disclosure, in specified circumstances, of major assumptions concerning future events affecting classes of provisions and (b) IFRS13; Fair Value Measurements which requires disclosure of significant assumptions (including the valuation technique(s) and inputs the entity has used in measuring the fair values of assets and liabilities that are carried at fair value.

Once an issue has been identified as being in the scope of either Judgment (IAS 1:122) or Estimation(s) (IAS 1;125), disclosures will need to be separately provided as a note or separate section of the notes of accounting policies with cross references, where appropriate, to other notes where further details may be found. However, a disclosure is not required for assets and liabilities measured at fair value if this is based on quoted prices in an active market for an identical asset or liability. The difference between these two requirements is not that one involves the exercise of judgement and the other does not. Rather, the difference is that disclosures in paragraph122 of particular judgements that management has made in the process of applying the entity's accounting policies do not relate to the disclosure of sources of estimation uncertainty regarding measurements in paragraph 125. The judgements relating to implementation of accounting policies disclosed under IAS 1:122 explicitly exclude those that involve estimations, which are addressed by the requirements of IAS 1:125.

\section{Empirical Studies}

Relevant IAS-IFRSs and empirical studies related to judgments and estimates under $I A S$ lare reviewed in this section. Paragraphs 122 and125 of IAS 1 set out the requirements for most of the judgements and estimates. The judgements and estimates referred to in IAS 1 affect current and future accounts differently. This is reflected in the different disclosure requirements. Paragraph 122 (of IAS 1) requires disclosure of judgements made by management in applying an entity's accounting policies, but does not apply to those relating to estimates (measurements). Paragraph 125 (of IAS 1) requires disclosure of information about the assumptions a reporting entity has made about the future, and other major sources of estimation uncertainty at the end of the reporting period, that have a significant risk of resulting 
in a material adjustment to the carrying amounts of assets and liabilities within the next financial year.

The Financial Reporting Council [9] of the UK undertook a thematic review of published annual financial statements of UK companies under the requirements of judgments and estimates, i.e., IAS 1:122 and IAS 1:125 respectively. The Review reported its findings under three headings; (a) differentiation of judgments from estimates, (b) judgments and (c) estimates. In relation to separate disclosure of judgments from estimates, the study found that a third of companies reviewed did not clearly distinguish judgements from estimates. A further $15 \%$ classified estimations involving judgement as "judgements" rather than estimates, which led to less disclosure around the specific amounts of risk and the sensitivities and range of outcomes of the amounts involved. In relation to judgments, the study found that a fifth of the companies reviewed used boilerplate text in the disclosure of at least some of their key judgments. These referred to particular items in the accounts but did not give details of the areas of subjectivity or the basis for management's judgment. Regarding estimates, the study made several findings: Firstly, over two-thirds of the companies reviewed disclosed estimates which, although relating to material amounts, did not appear to have a significant risk of resulting in a material adjustment to the carrying amounts of assets and liabilities at all. A common example was the disclosure of estimates around goodwill impairments. The related note stated that the directors did not believe that a reasonable possibility existed that a change in the key assumptions on which the recoverable amount was based would cause the carrying amount to exceed its recoverable amount. Secondly, the Financial Reporting Council [9] found that a third of the sample used boilerplate language when disclosing estimates. The most commonly identified examples of this related to taxation, useful economic lives, and debtor and stock provisions. In many cases, the disclosures could apply to any reporting entity and gave no additional useful information to users of the accounts. Also, only $40 \%$ of the companies surveyed consistently quantified the specific amounts at risk of material misstatement arising from the estimated amounts within the next financial year. Thirdly, assumptions underlying estimates were not quantified. There were situations where assumptions needed to be quantified in order for investors to be able to understand the positions taken by management. This was particularly relevant in industries where certain matters were likely to be significant sources of estimation uncertainty for all industry participants and where investors would want to make intercompany comparisons. About $90 \%$ of the companies surveyed provided sensitivity or range of outcome disclosures for at least some of the estimates disclosed. However, these tended to be only in areas where this disclosure was required by another accounting standard, such as impairments and pensions. Although tax assets and liabilities were the second most common sources of estimation uncertainty, it was noted that only two of the companies reviewed provided any sensitivity or range of outcome information in this area. None of the companies reviewed provided sensitivity disclosures for useful economic lives, despite this being a commonly cited source of estimation uncertainty. Finally, where a change in past assumptions amounted to a significant change in accounting estimate, $I A S \&$ requires disclosure of the nature and amount of the change. However, of the companies reviewed, just two disclosed a significant change in accounting estimate and a further three disclosed a more minor change in assumptions. Only one provided all the necessary disclosures required by IAS 8 .

The Irish Auditing and Accounting Supervisory Authority (IAASA) [12], also undertook a desk top survey on matters identified by companies as constituting critical accounting judgements. IAASA's [12] survey was based on the annual financial reports published by 20 randomly selected Irish corporations covering a cross-section of industry sectors, ranging in terms of market capitalisation, from larger- sized to smaller-sized entities. The primary purpose of the survey was to determine the critical accounting judgements which the selected corporations considered to be the most significant when preparing the 2014/15 financial statements. The study identified a total of 108 critical accounting judgement areas of which the most common critical accounting judgements made were: (a) Taxation, (b) Retirement benefit obligations (c) Goodwill impairment and (d) Provisions. The number of critical accounting judgements disclosed and reported by the corporations ranged from three in one set of financial statements to ten in another. Regarding where the critical accounting judgments were disclosed (i.e., whether the reporting was as a separate note within the financial statements, within the accounting policies note, or embedded in the relevant note to the financial statements), the critical accounting judgments were disclosed as a separate note within the financial statements $(60 \%)$, within the accounting policies note $(25 \%)$ and in the relevant note to the accounting statements (15\%).

Mayorga and Sidhu [13] investigate compliance with regulatory requirements by the largest 20 Australian listed firms to disclose key assumptions and major sources of estimation uncertainties and found that while firms provide some disclosure, the information was not sufficiently informative to give users meaningful insights. Overall, the level of disclosure fell short of the intentions of the relevant requirements. Another empirical study reviewed is that which is undertaken each year by Ernest and Young [14], an international accounting firm. Ernest and Young [14] closely monitor the Securities and Exchange Commission (SEC) staff comments on public reporting entity filings to provide insights on SEC areas of focus. Ernest and Young [14] reaffirmed the two conditions requiring disclosure of critical accounting estimates and judgments being: (i) the materiality of the nature of the estimates or assumptions as to the levels of subjectivity and judgment needed to account for highly uncertain matters susceptible to change; and (ii) the materiality of the effect of the estimates and assumptions to the financial statements. Ernest and Young [14] reported SEC 
staff observation that the critical accounting estimates were often too general; lacked specific disclosure of the methods used in the companies' critical accounting measurements as well as the quality and variability of management's judgments. The SEC staff also commented on the numerous perennial verbatim repetitions of portions of the significant accounting policies.

\section{The Research Method}

The scope of this study is an analysis of disclosures of significant accounting judgments and sources of estimation uncertainties of companies listed in the consumer goods section of the Nigerian Stock Exchange for the 2017 reporting period which is the most recent period in which the relevant data for the study is available. The population of the study consists of all the 20 companies in the consumer goods sector of the main board of the Nigerian Stock Exchange. A workable sample of 17 companies was arrived after excluding companies with "compliance status deficiencies" as explained below:

Table 1. Sample Size Selection Criteria.

\begin{tabular}{ll}
\hline Criteria & Number of companies \\
\hline Number of companies in the consumer goods sector & 20 \\
Number of companies with compliance "Below Listing Status" & $(1)$ \\
Number of companies that "Missed Regulatory Filling" & $(1)$ \\
Number of companies "Delisting in Progress" & $(1)$ \\
Number of companies Sampled & 17 \\
\hline
\end{tabular}

Appendix 1 report in details the full list of sampled companies including their external auditors, the financial reporting date (year-end date), the date that the financial statement is approved along with the number of pages of the annual financial reports.

\section{Results and Discussion}

In this paper, published annual reports of 17 consumer goods firms listed on the Nigerian Stock exchange were surveyed to determine how judgements and estimates were disclosed, as well as to identify the major sources of these disclosures. This is an important issue to academics, practitioners and accounting regulators in helping ascertain whether these firms clearly communicate to investors or simply drown the investors in a sea of numbers. In line with our objectives the results are presented and analysed in five main study objectives.

\subsection{Separate Disclosures of Judgments and Estimates}

Regulators expect judgements and estimates to be separately identified and relevant disclosures to be provided for each. From the analysis in this paper, only six (6) companies, representing $35 \%$ of the sampled companies (3, $4,6,11,13 \& 17)^{2}$ clearly distinguished judgments and estimates under different sub-headings. The other eleven sampled companies (65\%) combined disclosures about accounting estimates and judgments, referring to both in the same paragraph. This practice is out of line with the provision of the IAS 1 (see Appendices 2A \& 2B). Obviously, disclosures incongruent with the provisions of accounting standards are assumed to be of a lower disclosure quality than those presented as required by the standards. Paragraphs 122 and 125 of IAS 1 require separate disclosure of the judgments made in the process of applying the entity's

2 The numbers in parenthesis correspond to the serial number indicating the specific company name in Appendix 1. accounting policies and estimates, (i.e., measurements) that have the most significant effect on the amounts recognized in the financial statements.

\subsection{Judgements, Estimates and Their Effect on the Financial Statements}

On the whole, it was observed that judgment and estimate disclosures were boilerplate in nature and did not provide sufficiently useful information about the specific reporting entity's circumstances. Boilerplate disclosures are generic and potentially apply to any reporting entity. Consider the following disclosure of critical judgment about Revenue Recognition which is generic and could apply to any reporting entity by Honeywell Flour Mills Plc [15]:

The company makes provisions for trade discounts, volume rebates and charge back for product returns allowed by the sale contracts when recognising the revenue derived from sales of its products. Such deductions represent estimates, which are subject to judgments and assumptions based on past experience as well as the company's knowledge available at the time the estimate was made (p.47).

Identical disclosures were also observed from different reporting entities. For example Dangote Sugar Refinary Plc [16] and Nestle Nigeria Plc [17] both cite "Valuation of deferred tax" as a source of estimation uncertainty; and both companies reported their disclosures in identical words:

The recognition of deferred tax assets requires an assessment of future taxable profit. Deferred tax assets are only recognised to the extent that it is probable that taxable profits will be available against which deductible temporary differences can be valued. The availability of future taxable profits depend on several factors including the group's future financial performance and if necessary, implementation of tax planning strategies(p.45) and (p.39) respectively.

Similarly, NASCON Allied Industries Plc [18] and Flour Mills of Nigeria Plc [19] identified "Allowance for credit losses" as constituting a source of estimation uncertainty both disclosing in identical words; words which could potentially 
apply to any reporting entity:

The company periodically assesses its trade receivables for probability of credit losses. Management considers several factors including past credit record, current financial position and credibility of management, judgment is exercised in determining the allowances made for credit losses.

Provisions are made for receivables that have been outstanding for 365 days, in respect of which there is no firm commitment to pay by the customer.

Furthermore, all businesses are reviewed for evidence of impairment and provided against once recovery is doubtful. These assessments are subjective and involve a significant element of judgment by management on the ultimate recoverability of the amounts receivable (p.33) and (p.33) of [18] and [19] respectively

The spirit of IAS 1:122 is that companies should provide detailed descriptions of the specific, material judgments in applying accounting policies. From the thematic survey in this study, the majority (65\%) did not distinguish judgments (paragraph 122) from estimates (paragraph 125). Of the $35 \%$ that distinguished judgments and estimates, some firms misclassified judgments and estimates/measurements. For example, "write down of inventories to their net realisable values" (disclosed by Enamelware Nigeria [20]) is a measurement base (IAS 1: 118) rather than an exercise of judgement that has a significant risk of resulting in material adjustment to carrying amounts in the next financial year. Also, while management judgement is required to determine the amount of deferred taxation that can be recognized, based upon the likely timing and level of future taxable profits, deferred taxation is a judgment in estimation under IAS 1:125 rather than a model/judgment under IAS 1: 122 . Furthermore, some companies may have been under the illusion that judgments and estimates must be disclosed. The issue is not about stating several judgements and estimates but about providing richer information on significant accounting choices and measurement assumptions made. In the event that a reporting entity has not exercised judgement significant enough to require disclosure, it is helpful to state this explicitly [9]. Disclosure of non- exercise of judgment under IAS 1: 122 could be made in the following or similar phraseology (adapted from RPS) [21]:

"In the course of preparing the financial statements, no judgements have been made in the process of applying...accounting policies, other than those involving estimations... that have had a significant effect on the amounts recognised in the financial statements"'(p.43).

Regarding IAS 1:125, an observed common deficiency is the lack of a sufficient context or background information of key reasons supporting the conclusion explaining the extent to which changes in estimates could have had a material effect on the following year's accounts.

\subsection{What Constitutes Critical Judgments and Sources of Estimation Uncertainties}

The review of annual reports of the listed consumer goods firms in Nigeria indicates that there are 19 sources of judgments and estimations. The 19 items identified as major sources of estimation uncertainty in the financial statements varied by company (see Appendix 3). The number of items identified as critical accounting judgments and major sources of estimation uncertainty ranged from 1 to 13 per company with an average of 4 disclosure items per reporting entity. Analysis of the incidence of specific disclosure items is also presented in the graph in Figure 1 for more clarification.

From Figure 1 it can be observed that 13 out of 17 sampled companies indicate that they have made disclosures on "provisions and contingencies". This is followed by estimation of "useful lives and carrying amount of assets" with 9 companies. Defined obligations, pension and other employees benefit, and the impairment of assets and investments were the next more judgemental and estimation issues in the annual reports of consumer goods firms in Nigeria

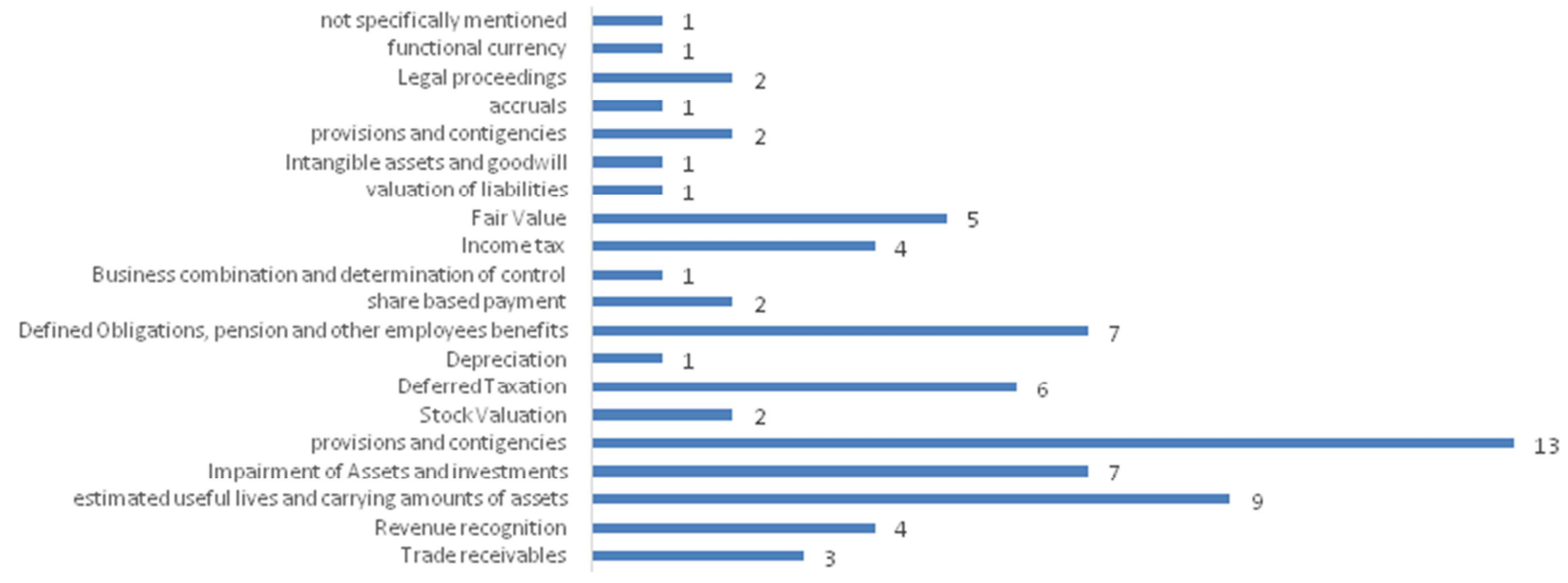

Figure 1. The Bar chart Showing the Sources of Judgements and Estimation.

\subsection{Location of Disclosures}

Disclosures of critical accounting judgments and estimates by the sampled Nigerian consumer goods companies were located; (a) within the "Notes to the Financial Statements" 
(47\%), (b) within the "Basis of Preparation" (29\%) and (c) within the "Accounting Policies Notes" (24\%). Table 2 presents the location details of disclosure of judgments and sources of estimation uncertainties.

Table 2. Location of disclosures.

\begin{tabular}{|c|c|c|c|c|}
\hline \multirow{2}{*}{$\mathbf{S} / \mathbf{N}$} & \multirow{2}{*}{ Name of company } & \multicolumn{3}{|c|}{ Location in the Accounts } \\
\hline & & Notes & Accounting policies & Basis of Preparation \\
\hline 1 & Cadbury Nigeria Plc & & & $\sqrt{ }$ \\
\hline 2 & Champion Breweries Plc & & & $\sqrt{ }$ \\
\hline 3 & Dangote Flour Mills Plc & $\sqrt{ }$ & & \\
\hline 4 & Dangote Sugar Refinery Plc & $\sqrt{ }$ & & \\
\hline 5 & Flour Mills of Nigeria Plc & $\sqrt{ }$ & & \\
\hline 6 & Guinness Nigeria Plc & $\sqrt{ }$ & & \\
\hline 8 & International Breweries Plc & & $\sqrt{ }$ & \\
\hline 9 & Northern Nigeria Flour Mills Plc & $\sqrt{ }$ & & \\
\hline 10 & NASCON Allied Industries Plc & & $\sqrt{ }$ & \\
\hline 11 & Nestle Nigeria Plc & $\sqrt{ }$ & & \\
\hline 12 & Nigerian Breweries Plc & & & $\sqrt{ }$ \\
\hline 13 & Nigerian Enamelware Plc & $\sqrt{ }$ & & \\
\hline 14 & PZ Cussons Nigeria Plc & & $\sqrt{ }$ & \\
\hline 15 & Unilever Nigeria Plc & $\sqrt{ }$ & & \\
\hline 17 & Vitafoam Plc & & $\sqrt{ }$ & \\
\hline \multicolumn{2}{|c|}{ Total number of companies } & 8 & 4 & 5 \\
\hline \multicolumn{2}{|c|}{ (Percentage $(\%)$ ) } & $(47 \%)$ & $(24 \%)$ & $(29 \%)$ \\
\hline
\end{tabular}

\subsection{Supplementary Disclosures Relating to Estimates of Uncertainties}

Companies are expected to disclose how sensitive carrying amounts are to assumptions upon which the estimates are based and/or the range of possible outcomes. Except in areas where this disclosure is required by another accounting standard, such as fair value measurement, impairments and pensions, disclosure of estimation uncertainties focused mainly on the process of calculating the amounts shown in the financial statements in general terms. Key assumptions were not quantified. There were almost no sensitivity analyses (except the effect of foreign currency exchange rate fluctuations by Guinness Nigeria Plc) showing the effect of a change in assumptions on the estimated amounts, neither was there a discussion of the likelihood of a significant change from the reported numbers.

\section{Conclusion and Recommendations}

This paper is based on a thematic survey of the published financial statements of companies in Nigeria to determine their level of compliance with regulatory requirements in disclosing the critical accounting judgments and major sources of estimation uncertainties. Strict compliance to these disclosures is required by standard setters and regulators to enhance high quality disclosures in this area. It is expected that such disclosures would enable financial statement users assess the quality of management's accounting policy decisions and the likelihood of future changes in the amounts in a way that generic disclosures do not. It was found that firms provide some disclosures, but the manner of disclosure is not sufficiently informative to give users meaningful insights into the performance and financial position of the reporting entities. Overall, the level of disclosure falls short of the intentions of the relevant regulatory requirements.

The findings suggest that in addition to the guidance in the IFRS illustrative examples, it may be necessary to train accountants and auditors in Nigeria on the disclosure of critical judgments and sources of estimation uncertainties to improve compliance and thus increase the informational value these disclosures contribute to financial reports.

\section{Appendix}

Table A1. List of Sampled Companies.

\begin{tabular}{|c|c|c|c|c|c|c|}
\hline $\mathbf{S} / \mathbf{N}$ & Companies & Auditor & $\begin{array}{l}\text { Auditors' } \\
\text { Remuneration } \$ 000\end{array}$ & $\begin{array}{l}\text { Reporting } \\
\text { Date }\end{array}$ & Approval Date & $\begin{array}{l}\text { Annual } \\
\text { Report Pages }\end{array}$ \\
\hline 1 & Cadbury Nigeria Plc & KPMG & $\approx 24,000$ & $31 / 12 / 2016$ & $14 / 03 / 2017$ & 75 \\
\hline 2 & Champion Breweries Plc & KPMG & $\mathrm{N} 10,454$ & $31 / 12 / 2016$ & $8 / 03 / 2017$ & 47 \\
\hline 3 & Dangote Flour Mills Plc & Deloitte & $\$ 83,000$ & $31 / 12 / 2016$ & $24 / 03 / 2017$ & 73 \\
\hline 4 & Dangote Sugar Refinery Plc & Deloitte & $\$ 52,920$ & $31 / 12 / 2016$ & $16 / 03 / 2017$ & 93 \\
\hline 5 & Flour Mills of Nigeria Plc & KPMG & $\approx 228,931$ & $31 / 03 / 2016$ & $14 / 07 / 2016$ & 101 \\
\hline 6 & Guinness Nigeria Plc & PWC & $\$ 30,000$ & $30 / 06 / 2016$ & $19 / 09 / 2016$ & 67 \\
\hline 7 & Honeywell Flour Mill Plc & BBC Professionals & $\mathrm{N} 15,000$ & $31 / 03 / 2016$ & $20 / 09 / 2016$ & 54 \\
\hline
\end{tabular}




\begin{tabular}{|c|c|c|c|c|c|c|}
\hline $\mathbf{S} / \mathbf{N}$ & Companies & Auditor & $\begin{array}{l}\text { Auditors' } \\
\text { Remuneration }{ }^{\prime} 000\end{array}$ & $\begin{array}{l}\text { Reporting } \\
\text { Date } \\
\end{array}$ & Approval Date & $\begin{array}{l}\text { Annual } \\
\text { Report Pages }\end{array}$ \\
\hline 8 & International Breweries Plc & Baker Tilly & $¥ 21,000$ & $31 / 03 / 2016$ & $5 / 05 / 2016$ & 40 \\
\hline 9 & Northern Nig. Flour Mills Plc & Deloitte \& Aminu Ibrahim & $¥ 14,500$ & $31 / 03 / 2016$ & $28 / 06 / 2016$ & 61 \\
\hline 10 & NASCON Allied Industries Plc & Deloitte & 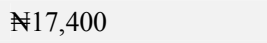 & $31 / 12 / 2016$ & $28 / 03 / 2017$ & 64 \\
\hline 11 & Nestle Nigeria Plc & Deloitte & $¥ 32,400$ & $31 / 12 / 2016$ & $28 / 02 / 2017$ & 78 \\
\hline 12 & Nigerian Breweries Plc & Deloitte & $¥ 49,591$ & $31 / 12 / 2016$ & $15 / 02 / 2017$ & 101 \\
\hline 13 & Nigerian Enamelware Plc & DOP \& Partners & $\$ 8,500$ & $30 / 04 / 2016$ & $14 / 07 / 2016$ & 57 \\
\hline 14 & PZ Cussons Nigeria Plc & PWC & $¥ 40,112$ & $31 / 05 / 2016$ & $2 / 08 / 2016$ & 54 \\
\hline 15 & UNILEVER Nigeria Plc & KPMG & $\approx 22,500$ & $31 / 12 / 2016$ & $10 / 03 / 2017$ & 80 \\
\hline 16 & Union DICON Salt & BDO Professionals & $\approx 2,300$ & $31 / 12 / 2016$ & $4 / 08 / 2017$ & 31 \\
\hline 17 & VITAFORM Nigeria Plc & Deloitte & $¥ 31,300$ & $30 / 09 / 2016$ & $15 / 12 / 2016$ & 69 \\
\hline
\end{tabular}

Table A2. Companies that differentiated Judgments from Estimates.

\begin{tabular}{|c|c|c|}
\hline Company & Judgments & Sources of Estimation Uncertainty \\
\hline \multirow{7}{*}{ Dangote Flour Mills } & Revenue Recognition & Trade Receivables \\
\hline & \multirow{6}{*}{$\begin{array}{l}\text { Expected manner of realisation for } \\
\text { deferred tax }\end{array}$} & Residual Values and lives of tangible and intangible assets \\
\hline & & Carrying values of intangible assets \\
\hline & & Impairment of assets \\
\hline & & Impairment of investments in subsidiaries \\
\hline & & Provisions \\
\hline & & Allowance for slow moving, damaged and obsolete stock \\
\hline \multirow{4}{*}{ Dangote Sugar Refinery } & Revenue Recognition & Useful life of PPE \\
\hline & Allowance for credit losses & \multirow{3}{*}{ Valuation of deferred tax } \\
\hline & Fair values of biological assets & \\
\hline & Growing sugar cane & \\
\hline \multirow{3}{*}{ Guinness Nigeria Plc } & $\begin{array}{l}\text { Recognition and measurements of } \\
\text { impairments }\end{array}$ & $\begin{array}{l}\text { Depreciation of PPE and other assets } \\
\text { Measurement of defined obligations: key actuarial assumptions }\end{array}$ \\
\hline & \multirow{3}{*}{$\begin{array}{l}\text { Provisions for trade and other receivables } \\
\text { Measurement of fair values }\end{array}$} & Share-based payments \\
\hline & & $\begin{array}{l}\text { Recognition and measurements of provisions and contingencies: Key } \\
\text { assumptions about the likelihood and magnitude of an outflow of resources }\end{array}$ \\
\hline \multirow{3}{*}{ Nestle Nigeria } & & Provision for employee benefits \\
\hline & \multirow[t]{2}{*}{ Allowance for credit losses } & Estimated useful lives and residual values of PPE \\
\hline & & Valuation of deferred tax \\
\hline \multirow{3}{*}{ Enamelware Nigeria } & Revenue recognition & Useful lives of PPE \\
\hline & \multirow{2}{*}{$\begin{array}{l}\text { Write down of inventories to net realisable } \\
\text { values }\end{array}$} & Allowance for doubtful debts/receivables \\
\hline & & Impairments of financial assets \\
\hline \multirow{6}{*}{ VITAFOAM } & Impairments of non-financial assets & Business combination \\
\hline & $\begin{array}{l}\text { Consolidation of a new subsidiary } \\
\text { Investments in a subsidiary }\end{array}$ & Assessment of control and significant influence \\
\hline & Functional currency relating to underlying & Pension obligations \\
\hline & events and conditions & Income taxes \\
\hline & Imnairments of financial acse & Impairments of available -for-sale equity investments \\
\hline & Imparrments or rinancial assets & Useful lives and residual values \\
\hline
\end{tabular}

Table A3. Companies that did not differentiate Judgments from Estimates.

\begin{tabular}{ll}
\hline Company & Judgments and Estimates \\
\hline & Deferred taxation \\
Cadbury Nigeria & Employee benefits \\
& Share-based payment Plans \\
& Trade and other payables \\
& Contingent liabilities and commitments \\
& Measurement of employee benefits: key actuarial assumptions \\
& Provisions and contingencies \\
Champion Breweries & Deferred taxation \\
& Measurement at fair values \\
& Biological assets \\
& Allowance for credit losses \\
Flour Mill of Nigeria & PPE \\
& Contingencies \\
& Valuation of financial liabilities \\
\hline
\end{tabular}




\begin{tabular}{|c|c|}
\hline Company & Judgments and Estimates \\
\hline & Provision of gratuity \\
\hline & Provision for long term service award \\
\hline & Taxation \\
\hline & Impairment of goodwill \\
\hline & Measurement at fair value \\
\hline & Measurement of defined benefit obligations \\
\hline Honeywell Flour Mills & Provisions and contingencies \\
\hline \multirow[t]{2}{*}{ International Breweries } & Not specified \\
\hline & PPE \\
\hline \multirow{3}{*}{ Northern Nigeria Flour Mills } & Provision for gratuity \\
\hline & Allowance for doubtful receivables \\
\hline & Taxation \\
\hline \multirow{2}{*}{ NASCON } & Allowance for credit loses \\
\hline & Useful life of PPE \\
\hline \multirow{4}{*}{ NB } & Intangible assets and goodwill: key assumptions underlying recoverable amounts of CGU \\
\hline & Measurements of defined obligations: key actuarial assumptions \\
\hline & Contingencies: key assumptions about likelihood and magnitude of an outflow of resources \\
\hline & Measurement of fair values \\
\hline \multirow{4}{*}{ PZ CUSSONS } & Revenue recognition \\
\hline & Impairment of financial assets \\
\hline & Impairment of non-financial assets \\
\hline & Useful lives of PPE \\
\hline \multirow{4}{*}{ UNILEVER } & Defined pension obligations \\
\hline & Recognition and measurement of contingencies \\
\hline & Determining fair values of stake holders' scheme \\
\hline & Determining accruals for custom duties and marketing expenses \\
\hline \multirow{4}{*}{ Union DICON Salt } & Legal proceedings \\
\hline & Income and deferred taxation \\
\hline & Impairment of PPE and intangible assets \\
\hline & Estimates of useful lives and residual values \\
\hline
\end{tabular}

Table A4. Sources of judgment and estimation uncertainties by each company.

\begin{tabular}{|c|c|c|c|c|c|c|c|c|c|c|c|c|c|c|c|c|c|c|}
\hline Sources/Companies & 1 & 2 & 3 & 4 & 5 & 6 & 7 & 8 & 9 & 10 & 11 & 12 & 13 & 14 & 15 & 16 & 17 & Total \\
\hline Trade receivables & $\sqrt{ }$ & & $\sqrt{ }$ & & & $\sqrt{ }$ & & & & & & & & & & & & 3 \\
\hline Revenue recognition & & & $\sqrt{ }$ & $\sqrt{ }$ & & & & & & & $\sqrt{ }$ & & & $\sqrt{ }$ & & & & 4 \\
\hline Residual value or carrying amounts & & & $\sqrt{ }$ & $\sqrt{ }$ & & & & & $\sqrt{ }$ & $\sqrt{ }$ & $\sqrt{ }$ & & $\sqrt{ }$ & $\sqrt{ }$ & & $\sqrt{ }$ & $\sqrt{ }$ & 9 \\
\hline $\begin{array}{l}\text { Impairment of Assets and } \\
\text { investments }\end{array}$ & & & $\sqrt{ }$ & & $\sqrt{ }$ & $\sqrt{ }$ & & & & & & & $\sqrt{ }$ & $\sqrt{ }$ & & $\sqrt{ }$ & $\sqrt{ }$ & 7 \\
\hline Provisions and contingencies & $\sqrt{ }$ & $\sqrt{ }$ & $\sqrt{ }$ & $\sqrt{ }$ & $\sqrt{ }$ & $\sqrt{ }$ & $\sqrt{ }$ & & $\sqrt{ }$ & $\sqrt{ }$ & $\sqrt{ }$ & $\sqrt{ }$ & $\sqrt{ }$ & & $\sqrt{ }$ & & & 13 \\
\hline Stock Valuation & & & $\sqrt{ }$ & & & & & & & & & & $\sqrt{ }$ & & & & & 2 \\
\hline Deferred Taxation & $\sqrt{ }$ & $\sqrt{ }$ & $\sqrt{ }$ & $\sqrt{ }$ & & & & & & & $\sqrt{ }$ & & & & & $\sqrt{ }$ & & 6 \\
\hline Depreciation & & & & & & $\sqrt{ }$ & & & & & & & & & & & & 1 \\
\hline $\begin{array}{l}\text { Defined Obligations, pension and } \\
\text { other employees benefits }\end{array}$ & & $\sqrt{ }$ & & & $\sqrt{ }$ & $\sqrt{ }$ & & & $\sqrt{ }$ & & $\sqrt{ }$ & $\sqrt{ }$ & & & & & $\sqrt{ }$ & 7 \\
\hline Share based payment & $\sqrt{ }$ & & & & & $\sqrt{ }$ & & & & & & & & & & & & 2 \\
\hline $\begin{array}{l}\text { Business combination and } \\
\text { determination of control }\end{array}$ & & & & & & & & & & & & & & & & & $\sqrt{ }$ & 1 \\
\hline Income tax & $\sqrt{ }$ & & & & $\sqrt{ }$ & & & & $\sqrt{ }$ & & & & & & & $\sqrt{ }$ & & 4 \\
\hline Fair Value & $\sqrt{ }$ & & & & & $\sqrt{ }$ & & & & & & $\sqrt{ }$ & & & $\sqrt{ }$ & & $\sqrt{ }$ & 5 \\
\hline Valuation of liabilities & & & & & $\sqrt{ }$ & & & & & & & & & & & & & 1 \\
\hline Intangible assets and goodwill & & & & & & & & & & $\sqrt{ }$ & & & & & & & & 1 \\
\hline Provisions and contingencies & & & & $\sqrt{ }$ & $\sqrt{ }$ & & & & & & & & & & & & & 2 \\
\hline Accruals & & & & & & & & & & & & & & & & $\sqrt{ }$ & & 1 \\
\hline Legal proceedings & & & & & & & & & & & & & $\sqrt{ }$ & & & $\sqrt{ }$ & & 2 \\
\hline Functional currency & & & & & & & & & & & & & & & & & $\sqrt{ }$ & 1 \\
\hline Not specifically mentioned & & & & & & & $\sqrt{ }$ & & & & & & & & & & & 1 \\
\hline Total & 6 & 3 & 7 & 5 & 6 & 7 & 1 & 1 & 4 & 3 & 4 & 3 & 5 & 3 & 2 & 6 & 6 & 73 \\
\hline
\end{tabular}




\section{References}

[1] Pivac, S., Vuko, T., \& Cular, M. (2017). Analysis of annual report disclosure quality for listed companies in transition countries. Economic Research-Ekonomska Istraživanja, 30(1), 721-731. doi:10.1080/1331677x.2017.1311231

[2] Levitt, A. (1997). The importance of high quality accounting standards, Remarks made at the Inter-American Development Washington D. C. on September 29, 1997 https://www.sec.gov/news/speech/speecharchive/1997/spch17 6.txt.

[3] Barth, M. E. (2006). Including Estimates of the Future in Today's Financial Statements, Accounting Horizons, 20: 27185.

[4] The International Financial Reporting Standards Foundation (2015). IAS 8 Accounting Policies, Changes in Accounting Estimates and Errors in a Briefing for Chief Executives, Audit Committees \& Boards of Directors. Availableathttps://circabc.europa.eu/webdav/CircaBC/ESTAT /ESTP/Library/2016\%20ESTP\%20PROGRAMME/05.\%20De sk $\% 20$ Profiling $\% 20 \%$ E2\%80\%93\%20Hands $\% 20 \mathrm{On} \% 2 \mathrm{C} \% 20$ $29 \% 20$ February\%20-\%204\%20March\%202016\%20$\% 20$ Organiser_\%20EUROSTAT/04.2\%20-\%20ESTP\%20$\% 20$ Desk $\% 20$ prof $\% 20$ -

\%20IFRS\%20briefing\%20book\%20(by\%20IASF)\%20(2015). pdf.

[5] Sacer, I., Malis, S. \&Pavic, I. (2016) The impact of accounting estimates on financial position and business performanceCase of non-current intangible and tangible assets, Procedia Economics and Finance, 39: 399$41 \mathrm{lhttps}: / /$ core.ac.uk/download/pdf/82820679.pdf.

[6] The Institute of Chartered Accountants of Scotland (ICAS, 2006). Principles not Rules. A Question of Judgement, Retrieved from https://www.icas.com/_data/assets/pdf_file/0020/2288/Princi ples-Not-Rules-A-Question-of-Judgement-ICAS.pdf.

[7] Pippin, R. (2009). SEC Disclosures Checklist. CCH Walters Kluwer Business.

[8] Herdman, R. (2002) Critical accounting and critical

disclosures: Speech by SEC Chief Accountant at Financial Executives International - San Diego on January, 24, 2002 https://www.sec.gov/news/speech/spch537.htm.

[9] The Financial Reporting Council (2017). Corporate Reporting Thematic Review, Judgments and Estimates Available at .

[10] International Accounting Standards committee Foundation (2010). IAS 1Presentation of Financial Statements, London: International Accounting Standards.

[11] Deloitte (2017). Spotlight on key judgements and estimates Available https://www2.deloitte.com/content/dam/Deloitte/ru/Document s/.../23-05-2017.pdf.

[12] The Irish Auditing and Accounting Supervisory Authority (IAASA, 2015). Survey of Directors' Critical Accounting Judgments and Auditors' Assessed Risks of Material Misstatement, https://www.iaasa.ie/.../2015_11_26-Survey-ofDirectors-Critical-Accounting-Judgment.

[13] Mayorga, D. \& Sidhu, B. (2012). Corporate Disclosure of the Major Sources of Estimation Uncertainties, Australian Accounting Review, 60(22):25-39.

[14] Ernest \& Young (2017). SEC Comments and Trends: An analysis of current reporting issues, www.ey.com/publication/vwluassetsdld/seccommentstrends.

[15] Honeywell Flour Mills Plc (2016). 2016 Annual Report and Financial Statements.

[16] Dangote Sugar Refinery (2017). 2016 consolidated and separate financial statements.

[17] Nestle Nigeria Plc (2017).2016 Annual Report and Financial Statements.

[18] Nascon Allied Industries Plc (2016). 2016 Financial Statements.

[19] Flour Mills of Nigeria Plc (2016). 2016 Annual Reports.

[20] Enamelware Nigeria Plc (2016). 2016 Annual Reports.

[21] RPS (2017). Annual Report and Accounts, Available at http://www.rpsgroup.com/resources/2016-annual-report/2016Report-Accounts.pdf. 